ARTICLE

\title{
Fast site-to-site electron transfer of high-entropy alloy nanocatalyst driving redox electrocatalysis
}

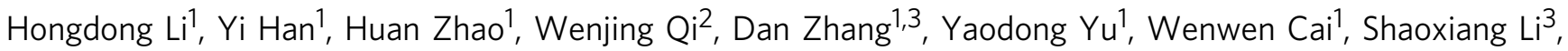
Jianping Lai ${ }^{1 凶}$, Bolong Huang (iD ${ }^{4 凶}$ \& Lei Wang (1) ${ }^{1,3 凶}$

Designing electrocatalysts with high-performance for both reduction and oxidation reactions faces severe challenges. Here, the uniform and ultrasmall $(\sim 3.4 \mathrm{~nm})$ high-entropy alloys (HEAs) $\mathrm{Pt}_{18} \mathrm{Ni}_{26} \mathrm{Fe}_{15} \mathrm{CO}_{14} \mathrm{Cu}_{27}$ nanoparticles are synthesized by a simple low-temperature oil phase strategy at atmospheric pressure. The $\mathrm{Pt}_{18} \mathrm{Ni}_{26} \mathrm{Fe}_{15} \mathrm{Co}_{14} \mathrm{Cu}_{27} / \mathrm{C}$ catalyst exhibits excellent electrocatalytic performance for hydrogen evolution reaction (HER) and methanol oxidation reaction (MOR). The catalyst shows ultrasmall overpotential of $11 \mathrm{mV}$ at the current density of $10 \mathrm{~mA} \mathrm{~cm}^{-2}$, excellent activity $\left(10.96 \mathrm{~A} \mathrm{mg}^{-1}{ }_{\mathrm{Pt}}\right.$ at $-0.07 \mathrm{~V} \mathrm{vs}$. reversible hydrogen electrode) and stability in the alkaline medium. Furthermore, it is also the efficient catalyst (15.04 $\mathrm{A} \mathrm{mg}^{-1} \mathrm{Pt}_{\mathrm{Pt}}$ ) ever reported for MOR in alkaline solution. Periodic DFT calculations confirm the multi-active sites for both HER and MOR on the HEA surface as the key factor for both proton and intermediate transformation. Meanwhile, the construction of HEA surfaces supplies the fast site-to-site electron transfer for both reduction and oxidation processes.

\footnotetext{
${ }^{1}$ Key Laboratory of Eco-chemical Engineering, Key Laboratory of Optic-electric Sensing and Analytical Chemistry of Life Science, Taishan Scholar Advantage and Characteristic Discipline Team of Eco Chemical Process and Technology, College of Chemistry and Molecular Engineering, Qingdao University of Science and Technology, 266042 Qingdao, P. R. China. ${ }^{2}$ College of Chemistry, Chongqing Normal University, 401331 Chongqing, P. R. China. ${ }^{3}$ Shandong Engineering Research Center for Marine Environment Corrosion and Safety Protection, College of Environment and Safety Engineering, Qingdao University of Science and Technology, 266042 Qingdao, P. R. China. ${ }^{4}$ Department of Applied Biology and Chemical Technology, The Hong Kong Polytechnic University, Hung Hom,

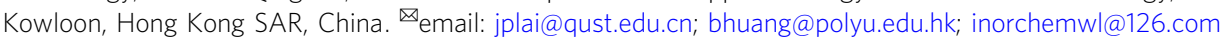


E lectrocatalytic processes play a vital role in energy conversion and reducing the environmental pollution ${ }^{1-5}$. To improve the activity, selectivity, and stability of the catalytic reaction, it is necessary to develop high-performance advanced catalysts that can meet the needs of rapid development ${ }^{6-12}$. High-entropy alloys (HEAs) have attracted wide interest as catalytic materials in the past few years ${ }^{13-16}$. The alloy contains five or more elements which have similar atomic ratios ${ }^{16,17}$. The atomic size of each component is different, which can cause lattice distortion ${ }^{18}$. Besides, the presence of multiple components is conducive to promoting the formation of the solid solution phase and inhibiting the movement of dislocations. These characteristics of HEA lead to some unique characteristics, such as strong fracture toughness, corrosion resistance, and high mechanical strength ${ }^{19-21}$. The ultimate goal of HEA is to adapt these characteristics to any desired response by using almost infinite possible combinations of elements and modifying their composition. In catalysis field, the adsorption of molecules and intermediates species on the surface of the catalyst affects the catalytic activity ${ }^{13,22}$. These adsorption energies can be adjusted by alloying as compared to pure elements to increase catalytic activity $^{23-25}$. Recently, some HEAs had used as catalysts for electrocatalytic reactions, which display superior stability and catalytic selectivity and activity compared with traditional alloys ${ }^{13,26-30}$. However, the traditional method mainly produce bulk HEAs rather than nanostructures ${ }^{26,31-34}$. Moreover, the preparation of uniform nanostructured HEAs with small size $(<10 \mathrm{~nm})$ currently requires specific equipment (fast heating/cooling rate, $\sim 10^{5} \mathrm{~K}$ per second), high temperature ( 2000 kelvin), and high temperature resistant and conductive substrate (carbon nanofiber), such as carbonthermal shock method ${ }^{35}$

In this work, taking into account the high abundance of $\mathrm{Ni}, \mathrm{Fe}$, $\mathrm{Co}$, and $\mathrm{Cu}$ and they can easily form solid solutions with Pt. These transition metal elements are selected because their similar atomic radius and lower heat of formation make them likely to form stable $\mathrm{HEAs}^{20,28}$. In addition, the DFT calculation provides a means to better understand the catalytic process and direct catalytic design ${ }^{13}$. Based on this, we synthesize the small size $(\sim 3.4 \mathrm{~nm})$ and uniform HEA $\mathrm{Pt}_{18} \mathrm{Ni}_{26} \mathrm{Fe}_{15} \mathrm{Co}_{14} \mathrm{Cu}_{27}$ nanoparticles (NPs) by a simple lowtemperature oil phase synthesis method at atmospheric pressure. The $\mathrm{Pt}_{18} \mathrm{Ni}_{26} \mathrm{Fe}_{15} \mathrm{Co}_{14} \mathrm{Cu}_{27} / \mathrm{C}$ catalyst displays a low overpotential $\left(11 \mathrm{mV}\right.$ at $\left.10 \mathrm{~mA} \mathrm{~cm}^{-2}\right)$, the activity of $10.96 \mathrm{~A} \mathrm{mg}^{-1}{ }_{\mathrm{Pt}}$ at $-0.07 \mathrm{~V}$ vs. reversible hydrogen electrode (RHE) for HER (reduction reaction) in $1 \mathrm{M} \mathrm{KOH}$ solution, and through the chronoamperometric method and 10,000th CV tests, it indicates that the notable stability of the HEA catalyst. We further also measure the electrocatalytic activity of $\mathrm{Pt}_{18} \mathrm{Ni}_{26} \mathrm{Fe}_{15} \mathrm{Co}_{14} \mathrm{Cu}_{27} / \mathrm{C}$ for MOR (oxidation reaction) at $1 \mathrm{M} \mathrm{KOH}+1 \mathrm{M} \mathrm{CH} \mathrm{CH}_{3} \mathrm{OH}$ electrolyte, it also exhibited high mass activity (15.04 $\left.\mathrm{A} \mathrm{mg}^{-1} \mathrm{Pt}\right)$. Theoretical calculations reveal that each element in HEA displays different contributions for the electrocatalysis process, which promotes the site-to-site electron transfer and the stabilization of the intermediates. HEA showed the multiactive sites for both HER and MOR for achieving superior performance and stability.

\section{Results}

Synthesis and characterizations of PtNiFeCoCu HEA NPs. $\mathrm{PtNiFeCoCu}$ HEA NPs were prepared through a simple one-pot oil phase synthesis method at $220^{\circ} \mathrm{C}$ for $2 \mathrm{~h}$. The inductively coupled plasma atomic emission spectroscopy (ICP-AES) result shows that the atomic ratio of $\mathrm{Pt}, \mathrm{Ni}, \mathrm{Fe}, \mathrm{Co}$, and $\mathrm{Cu}$ was 18:26:15:14:27 (Supplementary Table 1), the prepared NPs-HEA was named $\mathrm{Pt}_{18} \mathrm{Ni}_{26} \mathrm{Fe}_{15} \mathrm{Co}_{14} \mathrm{Cu}_{27}$. As shown in Fig. $1 \mathrm{a}, \mathrm{b}$, the transmission electron microscopy (TEM) images of $\mathrm{Pt}_{18} \mathrm{Ni}_{26}$ $\mathrm{Fe}_{15} \mathrm{Co}_{14} \mathrm{Cu}_{27}$ NPs display the morphology is uniform, and the diameter of $\mathrm{Pt}_{18} \mathrm{Ni}_{26} \mathrm{Fe}_{15} \mathrm{Co}_{14} \mathrm{Cu}_{27} \mathrm{NPs}$ is about $3.4 \pm 0.6 \mathrm{~nm}$ (the inset in Fig. 1a). The high-resolution TEM (HRTEM) (Fig. 1c) image of $\mathrm{Pt}_{18} \mathrm{Ni}_{26} \mathrm{Fe}_{15} \mathrm{Co}_{14} \mathrm{Cu}_{27} \mathrm{NPs}$ exhibits that the lattice spacing is $0.218 \mathrm{~nm}$, corresponding to the (111) facet. The powder X-ray diffraction (PXRD) pattern (Supplementary Fig. 1a) suggests the fcc structure of the NPs-HEAs, the two peaks at around $41.1^{\circ}$ and $47.8^{\circ}$, which can be assigned to the (111) and (200) facets. The position of the broad diffraction peak is significant shift compared with the diffraction peaks of pure $\mathrm{Pt}, \mathrm{Ni}$, $\mathrm{Fe}, \mathrm{Co}$, and $\mathrm{Cu}$ (Supplementary Fig. 1b), it shows that these elements have been introduced into the nanostructure to form HEAs structure. Figure 1d shows the elemental maps of NPsHEAs, $\mathrm{Pt}, \mathrm{Ni}, \mathrm{Fe}, \mathrm{Co}$, and $\mathrm{Cu}$ elements are uniformly distributed in the HEA nanostructure.

The X-ray photoelectron spectroscopy (XPS) of $\mathrm{Pt}_{18} \mathrm{Ni}_{26} \mathrm{Fe}_{15}$ $\mathrm{Co}_{14} \mathrm{Cu}_{27}$ NPs was tested, it also shows the presence of these Pt, $\mathrm{Ni}, \mathrm{Fe}, \mathrm{Co}$, and $\mathrm{Cu}$ elements (Supplementary Fig. 2a), the atomic ratio of $\mathrm{Pt}, \mathrm{Ni}, \mathrm{Fe}, \mathrm{Co}$, and $\mathrm{Cu}$ was 21.2:27.4:15.2:13.7:22.5, further proving that the HEA was successfully prepared. As shown in Supplementary Fig. $2 \mathrm{~b}$, the $\mathrm{Pt} 4 \mathrm{f}_{7 / 2}$ and $\mathrm{Pt} 4 \mathrm{f}_{5 / 2}$ peaks are located at 71.3 and $74.7 \mathrm{eV}$, respectively. Pt mainly exists in the form of zero valences and a small amount of $2+$ valence $^{29}$. The Ni $2 p$ spectra display the coexistence of $\mathrm{Ni}^{0}(852.8 \mathrm{eV})$ and $\mathrm{Ni}^{2+}(855.6$ $\mathrm{eV}$ ) and a satellite peak locate at $861.6 \mathrm{eV}$ (Supplementary Fig. 2c), the content of $\mathrm{Ni}^{0}$ is lower than the content of $\mathrm{Ni}^{2+}$ because of the high chemical activity of $\mathrm{Ni}^{28,29}$. The Fe $2 \mathrm{p}$ spectra in Supplementary Fig. 2d shows two peaks at $711.6 \mathrm{eV}$ and 724.8 $\mathrm{eV}$, which can be attributed to $\mathrm{Fe} 2 \mathrm{p}_{3 / 2}$ and $\mathrm{Fe} 2 \mathrm{p}_{1 / 2}$, respectively. The two Co $2 \mathrm{p}$ peaks can be assigned to Co $2 \mathrm{p}_{3 / 2}(780.8 \mathrm{eV})$ and Co $2 \mathrm{p}_{1 / 2}(797.0 \mathrm{eV})$ (Supplementary Fig. 2e). The Cu 2p spectra (Supplementary Fig. 2f) also exhibits $\mathrm{Cu}^{0}(931.7 \mathrm{eV})$ and $\mathrm{Cu}^{2+}$ $(933.5 \mathrm{eV})$ peaks coexist in the sample.

Electrocatalytic performance tests toward HER. In order to study the electrocatalytic performance of $\mathrm{PtNiFeCoCu} / \mathrm{C}$, we further treated with acetic acid to remove residual surfactants. From the FTIR spectrum (Supplementary Fig. 3), the acetic acidtreated sample (the purified $\mathrm{PtNiFeCoCu} / \mathrm{C}$ ), no obvious characteristic peaks corresponding to oleylamine and CTAC were observed $^{36}$. The HER (reduction reaction) activity and stability of the $\mathrm{Pt}_{18} \mathrm{Ni}_{26} \mathrm{Fe}_{15} \mathrm{Co}_{14} \mathrm{Cu}_{27} / \mathrm{C}$ catalyst were investigated by a series of electrochemical tests and compared with commercial $\mathrm{Pt} / \mathrm{C}$. The Pt size (about $3.0 \mathrm{~nm}$, Supplementary Fig. 4) on the Pt/C catalyst is similar to the size of HEA particles, so the electrocatalytic activity can be reasonably compared based on surface Pt sites. Figure $2 \mathrm{a}$ shows the $\mathrm{CV}$ curves of $\mathrm{Pt}_{18} \mathrm{Ni}_{26} \mathrm{Fe}_{15} \mathrm{Co}_{14} \mathrm{Cu}_{27} / \mathrm{C}$ and commercial $\mathrm{Pt} / \mathrm{C}$ catalysts in $\mathrm{N}_{2}$-saturated $1 \mathrm{M} \mathrm{KOH}$ at a scan rate of $20 \mathrm{mV} \mathrm{s}^{-1}$. After activation, the linear sweep voltammetry (LSV) curve of the $\mathrm{Pt}_{18} \mathrm{Ni}_{26} \mathrm{Fe}_{15} \mathrm{Co}_{14} \mathrm{Cu}_{27} / \mathrm{C}$ catalyst displays a low overpotential of $11 \mathrm{mV}$ at the current density of $10 \mathrm{~mA} \mathrm{~cm}^{-2}$ (normalized to the electrode area), which is far superior to commercial Pt/C catalyst $(84 \mathrm{mV}$ ) (Fig. 2b). As shown in Fig. 2b, $\mathrm{d}$, the area activity (normalized to the geometric area) of NPsHEAs $\mathrm{Pt}_{18} \mathrm{Ni}_{26} \mathrm{Fe}_{15} \mathrm{Co}_{14} \mathrm{Cu}_{27} / \mathrm{C}$ catalyst reaches $83.78 \mathrm{~mA} \mathrm{~cm}{ }^{-2}$ at $-0.07 \mathrm{~V}$ vs. RHE, far more than area activity of commercial $\mathrm{Pt} / \mathrm{C}$ catalyst $\left(8.42 \mathrm{~mA} \mathrm{~cm}^{-2}\right.$ at $-0.07 \mathrm{~V}$ vs. RHE). From the Fig. $2 \mathrm{c}$ (LSV curves, normalized to the Pt mass), the mass activity for commercial Pt/C catalyst and $\mathrm{Pt}_{18} \mathrm{Ni}_{26} \mathrm{Fe}_{15} \mathrm{Co}_{14} \mathrm{Cu}_{27} / \mathrm{C}$ catalyst are $0.83 \mathrm{~A} \mathrm{mg}^{-1}{ }_{\mathrm{Pt}}$ and $10.96 \mathrm{~A} \mathrm{mg}^{-1}{ }_{\mathrm{Pt}}$ at $-0.07 \mathrm{~V}$ vs. RHE (Fig. 2d), respectively. And the $\mathrm{Pt}_{18} \mathrm{Ni}_{26} \mathrm{Fe}_{15} \mathrm{Co}_{14} \mathrm{Cu}_{27} / \mathrm{C}$ catalyst also exhibits higher HER performance in alkaline medium among the reported Pt-based catalysts and HEAs catalysts (Supplementary Table 7). As shown in Fig. 2e, the Tafel slopes of $\mathrm{Pt}_{18} \mathrm{Ni}_{26^{-}}$

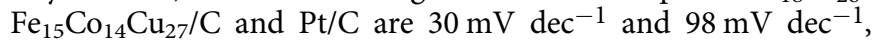
respectively, which demonstrate that the HEAs catalyst greatly boosts HER kinetics. 
a

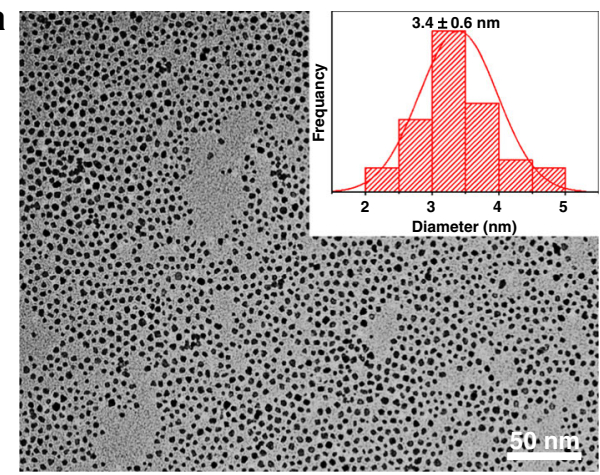

c

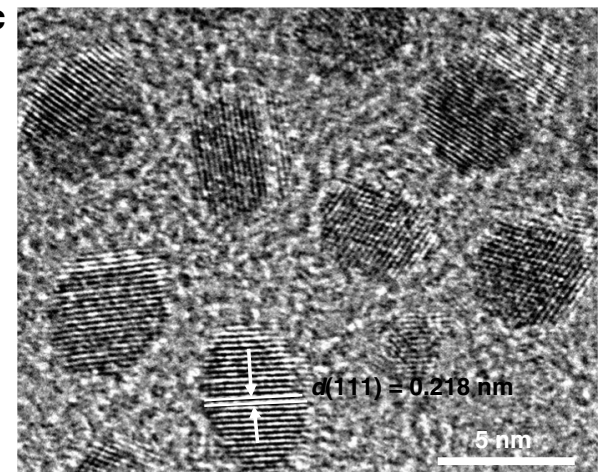

b

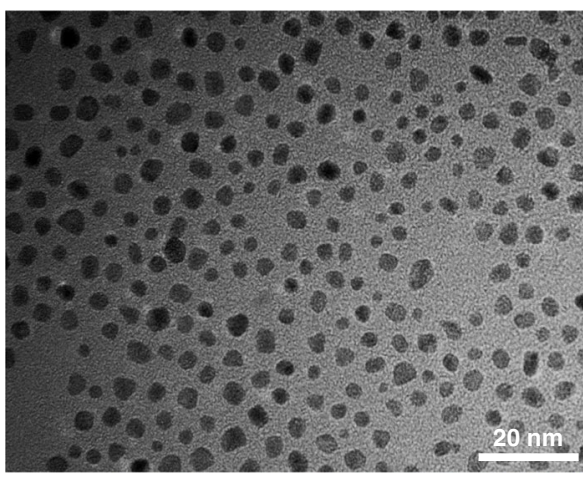

d
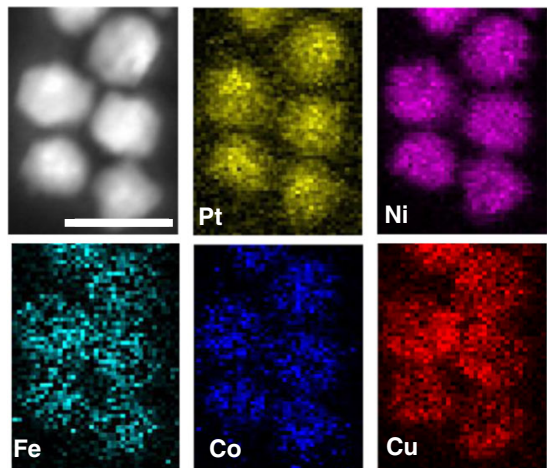

Fig. 1 TEM images and elemental mapping analysis. a, b TEM images of $\mathrm{Pt}_{18} \mathrm{Ni}_{26} \mathrm{Fe}_{15} \mathrm{Co}_{14} \mathrm{Cu}_{27}$ nanoparticles. $\mathbf{c} \mathrm{HRTEM}$ image of $\mathrm{Pt}_{18} \mathrm{Ni}_{26} \mathrm{Fe}_{15} \mathrm{Co}_{14} \mathrm{Cu}_{27}$ nanoparticles. $\mathbf{d}$ The corresponding elemental mapping of $\mathrm{Pt}_{18} \mathrm{Ni}_{26} \mathrm{Fe}_{15} \mathrm{Co}_{14} \mathrm{Cu}_{27}$ nanoparticles (scale bar, $5 \mathrm{~nm}$ ).

a

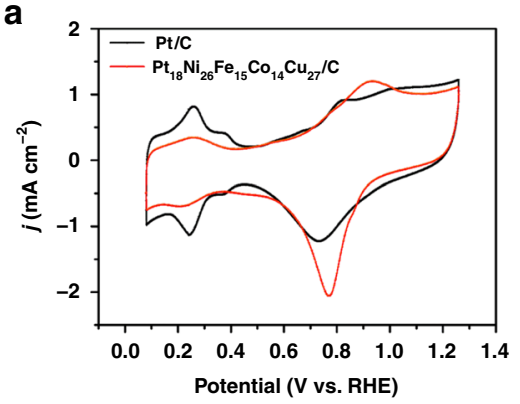

d

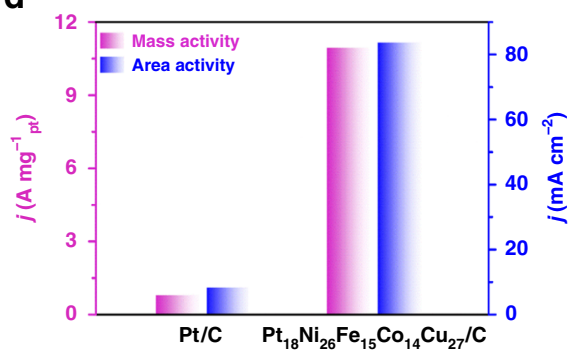

b
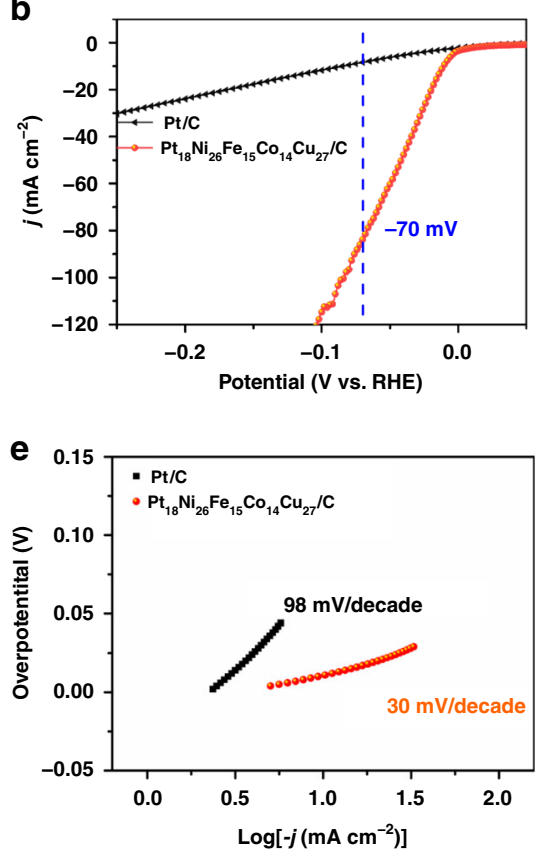

C

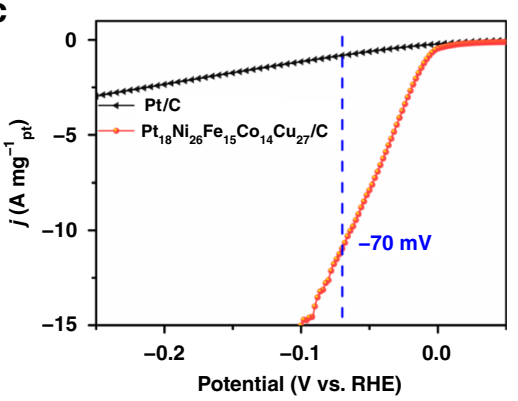

f

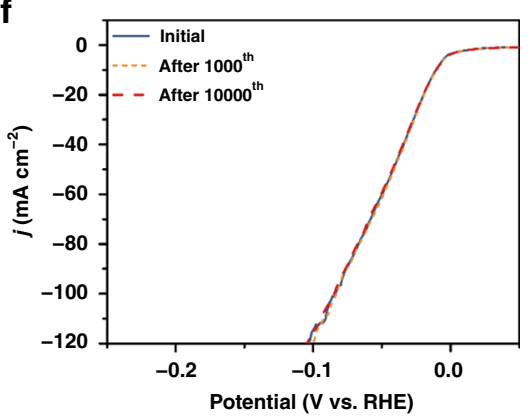

Fig. 2 Electrocatalytic performance of the $\mathbf{P t}_{\mathbf{1 8}} \mathbf{N i}_{26} \mathbf{F e}_{15} \mathbf{C O}_{{ }_{14}} \mathbf{C u}_{\mathbf{2 7}} / \mathbf{C}$ and $\mathrm{Pt} / \mathrm{C}$ for $\mathrm{HER}$ in $\mathbf{1} \mathbf{M} \mathbf{K O H}$ electrolyte. a CV curves. b HER polarization curves (geometrical area). c Pt mass loading normalized (mass activity) LSV curves. $\mathbf{d}$ Comparison of area activity and mass activity values for HER at $-70 \mathrm{mV}$ vs. RHE. e Tafel slope. $\mathbf{f} \mathrm{HER}$ polarization curves (geometrical area) for $\mathrm{Pt}_{18} \mathrm{Ni}_{26} \mathrm{Fe}_{15} \mathrm{Co}_{14} \mathrm{Cu}_{27} / \mathrm{C}$ with different $\mathrm{CV}$ cycle.

To better understand the HER performance of the $\mathrm{Pt}_{18} \mathrm{Ni}_{26} \mathrm{Fe}_{15^{-}}$ $\mathrm{Co}_{14} \mathrm{Cu}_{27} / \mathrm{C}$ catalyst, we tested the electrochemical double-layer capacitance, electrochemical impedance spectra, and turnover frequency (TOF). We found that the electrochemical double-layer capacitance of $\mathrm{Pt}_{18} \mathrm{Ni}_{26} \mathrm{Fe}_{15} \mathrm{Co}_{14} \mathrm{Cu}_{27} / \mathrm{C}$ catalyst is higher than that of commercial Pt/C catalyst (Supplementary Fig. 5), indicating that the
NPs-HEAs can expose more active sites. Also, electrochemical impedance spectra (Supplementary Fig. 6) exhibits $\mathrm{Pt}_{18} \mathrm{Ni}_{26} \mathrm{Fe}_{15^{-}}$ $\mathrm{Co}_{14} \mathrm{Cu}_{27} / \mathrm{C}$ catalyst has a smaller semicircular diameter than commercial $\mathrm{Pt} / \mathrm{C}$ catalyst, the transfer resistance of $\mathrm{Pt}_{18} \mathrm{Ni}_{26} \mathrm{Fe}_{15^{-}}$ $\mathrm{Co}_{14} \mathrm{Cu}_{27} / \mathrm{C}$ is much lower than that of commercial $\mathrm{Pt} / \mathrm{C}$ catalysts, indicating higher interfacial charge transfer rate and faster HER 
kinetics. The TOF value is used to characterize the activity of each site in the catalyst ${ }^{37}$. It is found that the TOF value of the $\mathrm{Pt}_{18} \mathrm{Ni}_{26} \mathrm{Fe}_{15} \mathrm{Co}_{14} \mathrm{Cu}_{27} / \mathrm{C}$ catalyst is higher than $\mathrm{Pt} / \mathrm{C}$ catalyst under various potentials (Supplementary Fig. 7), which shows the faster HER kinetics of $\mathrm{Pt}_{18} \mathrm{Ni}_{26} \mathrm{Fe}_{15} \mathrm{Co}_{14} \mathrm{Cu}_{27} / \mathrm{C}$ catalyst. These results further indicate that the NPs-HEAs can improve the catalytic activity effectively.

The stability of the catalysts was checked using the chronoamperometric method and 10,000 th $\mathrm{CV}$ in $1.0 \mathrm{M} \mathrm{KOH}$ solution. The stability of the $\mathrm{Pt}_{18} \mathrm{Ni}_{26} \mathrm{Fe}_{15} \mathrm{Co}_{14} \mathrm{Cu}_{27} / \mathrm{C}$ and $\mathrm{Pt} / \mathrm{C}$ catalysts were measured at an overpotential of $11 \mathrm{mV}$ and $84 \mathrm{mV}$ (under current density $10 \mathrm{~mA} \mathrm{~cm}^{-2}$ condition, Supplementary Fig. 8), respectively. After $10 \mathrm{~h}$ test, $99 \%$ of the current density is maintained for the $\mathrm{Pt}_{18} \mathrm{Ni}_{26} \mathrm{Fe}_{15} \mathrm{Co}_{14} \mathrm{Cu}_{27} / \mathrm{C}$ catalyst, while the current density of the $\mathrm{Pt} / \mathrm{C}$ catalyst is only kept about $53 \%$. To further evaluate the stability of $\mathrm{Pt}_{18} \mathrm{Ni}_{26} \mathrm{Fe}_{15} \mathrm{Co}_{14} \mathrm{Cu}_{27} / \mathrm{C}$ and $\mathrm{Pt} / \mathrm{C}$ catalysts, the 1000th and 10,000th $\mathrm{CV}$ cycles in $1 \mathrm{M} \mathrm{KOH}$ solution were performed. Figure $2 \mathrm{f}$ displays the LSV curves of $\mathrm{Pt}_{18} \mathrm{Ni}_{26} \mathrm{Fe}_{15} \mathrm{Co}_{14} \mathrm{Cu}_{27} / \mathrm{C}$ catalyst before and after 1000th and 10,000 th CV cycles. There is no obvious negative shift at the current density of $10 \mathrm{~mA} \mathrm{~cm}^{-2}$, exhibiting higher stability than $\mathrm{Pt} / \mathrm{C}$ catalyst (Supplementary Fig. 9, a negative shift of $\sim 33 \mathrm{mV}$ at $10 \mathrm{~mA} \mathrm{~cm}^{-2}$ after 10,000th $\mathrm{CV}$ cycles). In addition, the morphology (Supplementary Fig. 10), the atomic ratio (Supplementary Table 1), lattice spacing and the XRD peaks (Supplementary Fig. 11) of catalyst do not change significantly after the stability test. In addition, the slight variations in the stoichiometry (Supplementary Table 2) after the electrocatalytic test was caused by the leaching of non-noble metals $(\mathrm{Ni}, \mathrm{Fe}, \mathrm{Co}$, and $\mathrm{Cu})$ in the catalyst $^{38,39}$. XPS analysis (Supplementary Fig. 12) shows that the Pt $4 \mathrm{f}, \mathrm{Ni} 2 \mathrm{p}, \mathrm{Fe} 2 \mathrm{p}$, Co $2 \mathrm{p}$, and $\mathrm{Cu} 2 \mathrm{p}$ spectra of $\mathrm{Pt}_{18} \mathrm{Ni}_{26} \mathrm{Fe}_{15} \mathrm{Co}_{14} \mathrm{Cu}_{27} / \mathrm{C}$ were very similar before and after electrocatalysis, while the oxide species increased slightly (Supplementary Table 3). However, the $\mathrm{Pt} / \mathrm{C}$ catalyst shows obvious aggregation after the stability test (Supplementary Fig. 13). These results further suggest the excellent stability of the $\mathrm{Pt}_{18} \mathrm{Ni}_{26} \mathrm{Fe}_{15} \mathrm{Co}_{14} \mathrm{Cu}_{27} / \mathrm{C}$ catalyst.

Furthermore, taking the change of $\mathrm{Cu}$ element content as an example, the effect of stoichiometry variations on the electrocatalytic performance is discussed. Specifically, this synthesis method is used to prepare $\mathrm{PtNiFeCoCu}$ NPs with other $\mathrm{Cu}$ content ( $\mathrm{PtNiFeCoCu}_{26}$ with slight stoichiometry variations, $\mathrm{Pt}_{21} \mathrm{Ni}_{27} \mathrm{Fe}_{19} \mathrm{Co}_{17} \mathrm{Cu}_{16}$ and $\mathrm{Pt}_{15} \mathrm{Ni}_{24} \mathrm{Fe}_{13} \mathrm{Co}_{13} \mathrm{Cu}_{35}$ ) by changing the amount of $\mathrm{Cu}$ precursor. From Supplementary Fig. 14, the morphology and size of the $\mathrm{PtNiFeCoCu} 26, \mathrm{Pt}_{21} \mathrm{Ni}_{27} \mathrm{Fe}_{19} \mathrm{Co}_{17} \mathrm{Cu}_{16}$ and $\mathrm{Pt}_{15} \mathrm{Ni}_{24} \mathrm{Fe}_{13} \mathrm{Co}_{13} \mathrm{Cu}_{35}$ are similar to $\mathrm{Pt}_{18} \mathrm{Ni}_{26} \mathrm{Fe}_{15} \mathrm{Co}_{14} \mathrm{Cu}_{27}$ NPs. The PXRD pattern (Supplementary Fig. 15) suggests the fcc structure of the $\mathrm{PtNiFeCoCu}{ }_{26}, \mathrm{Pt}_{21} \mathrm{Ni}_{27} \mathrm{Fe}_{19} \mathrm{Co}_{17} \mathrm{Cu}_{16}$ and $\mathrm{Pt}_{15} \mathrm{Ni}_{24} \mathrm{Fe}_{13} \mathrm{Co}_{13} \mathrm{Cu}_{35}$ NPs. The HER performance of PtNiFe$\mathrm{CoCu}_{26} / \mathrm{C}$ catalyst with slight stoichiometry variations (Supplementary Figs. 16-24 and Supplementary Table 5) has no significant change compared with $\mathrm{Pt}_{18} \mathrm{Ni}_{26} \mathrm{Fe}_{15} \mathrm{Co}_{14} \mathrm{Cu}_{27} / \mathrm{C}(\mathrm{PtNi}-$ $\mathrm{FeCoCu}_{27} / \mathrm{C}$ ). After activation (Supplementary Fig. 16), the $\mathrm{PtNiFeCoCu}{ }_{26} / \mathrm{C}$ catalyst has close overpotential $(11 \mathrm{mV}$, Supplementary Fig. 17a), area activity and mass activity $(82.66 \mathrm{~mA}$ $\mathrm{cm}^{-2}$ and $10.81 \mathrm{~A} \mathrm{mg}^{-1}{ }_{\mathrm{Pt}}$ at $-0.07 \mathrm{~V}$ vs. RHE, Supplementary Fig. 17a-c), Tafel slope (30 mV $\mathrm{dec}^{-1}$, Supplementary Fig. 18a), electrochemical double-layer capacitance (7.01 mF, Supplementary Fig. 19a, d), electrochemical impedance (Supplementary Fig. 20a), TOF value (Supplementary Fig. 21a, c) and stability (Supplementary Figs. 22-24) compared with $\mathrm{PtNiFeCoCu}_{27} / \mathrm{C}$ catalyst. In addition, the $\mathrm{HER}$ performance of $\mathrm{Pt}_{21} \mathrm{Ni}_{27} \mathrm{Fe}_{19^{-}}$ $\mathrm{Co}_{17} \mathrm{Cu}_{16} / \mathrm{C}$ and $\mathrm{Pt}_{15} \mathrm{Ni}_{24} \mathrm{Fe}_{13} \mathrm{Co}_{13} \mathrm{Cu}_{35} / \mathrm{C}$ catalysts (Supplementary Figs. 16-24 and Supplementary Table 5) is slightly lower than the $\mathrm{Pt}_{18} \mathrm{Ni}_{26} \mathrm{Fe}_{15} \mathrm{Co}_{14} \mathrm{Cu}_{27} / \mathrm{C}$ catalyst. The order of activity is as follows: $\mathrm{Pt}_{18} \mathrm{Ni}_{26} \mathrm{Fe}_{15} \mathrm{Co}_{14} \mathrm{Cu}_{27} / \mathrm{C}\left(83.78 \mathrm{~mA} \mathrm{~cm}^{-2}\right.$ and $10.96 \mathrm{~A}$ $\mathrm{mg}^{-1}{ }_{\mathrm{Pt}}$ at $-0.07 \mathrm{~V}$ vs. $\left.\mathrm{RHE}\right) \approx \mathrm{PtNiFeCoCu}{ }_{26} / \mathrm{C}\left(82.66 \mathrm{~mA} \mathrm{~cm}^{-2}\right.$ and $10.81 \mathrm{~A} \mathrm{mg}^{-1} \mathrm{Pt}$ at $-0.07 \mathrm{~V}$ vs. $\left.\mathrm{RHE}\right)>\mathrm{Pt}_{21} \mathrm{Ni}_{27} \mathrm{Fe}_{19} \mathrm{Co}_{17} \mathrm{Cu}_{16} /$ $\mathrm{C}\left(74.21 \mathrm{~mA} \mathrm{~cm}^{-2}\right.$ and $9.65 \mathrm{~A} \mathrm{mg}^{-1} \mathrm{Pt}$ at $-0.07 \mathrm{~V}$ vs. RHE $)>$ $\mathrm{Pt}_{15} \mathrm{Ni}_{24} \mathrm{Fe}_{13} \mathrm{Co}_{13} \mathrm{Cu}_{35} / \mathrm{C}\left(59.76 \mathrm{~mA} \mathrm{~cm}^{-2}\right.$ and $7.88 \mathrm{~A} \mathrm{mg}^{-1}{ }_{\mathrm{Pt}}$ at $-0.07 \mathrm{~V}$ vs. RHE).

Electrocatalytic performance tests toward MOR. To further explore the $\mathrm{Pt}_{18} \mathrm{Ni}_{26} \mathrm{Fe}_{15} \mathrm{Co}_{14} \mathrm{Cu}_{27} / \mathrm{C}$ catalyst as redox bi-function electrocatalysts, we tested the MOR (oxidation reaction) activity. As shown in Fig. 3a and Supplementary Fig. 25, the $\mathrm{Pt}_{18} \mathrm{Ni}_{26}$ $\mathrm{Fe}_{15} \mathrm{Co}_{14} \mathrm{Cu}_{27} / \mathrm{C}$ catalyst shows higher activity compared to $\mathrm{Pt} / \mathrm{C}$ catalyst for $\mathrm{MOR}$ in $1 \mathrm{M} \mathrm{KOH}+1 \mathrm{M} \mathrm{CH}_{3} \mathrm{OH}$ electrolyte at a sweep rate of $20 \mathrm{mV} \mathrm{s}^{-1}$. And an onset potential (the mass activity of $0.1 \mathrm{~A} \mathrm{mg}^{-1} \mathrm{pt}$ ) was observed to decrease by $133 \mathrm{mV}$ in the $\mathrm{Pt}_{18} \mathrm{Ni}_{26} \mathrm{Fe}_{15} \mathrm{Co}_{14} \mathrm{Cu}_{27} / \mathrm{C}$ catalyst compared to the $\mathrm{Pt} / \mathrm{C}$ catalyst (the inset of Fig. 3a), indicating that the activation barrier of methanol oxidation is lower. The $\mathrm{Pt}_{18} \mathrm{Ni}_{26} \mathrm{Fe}_{15} \mathrm{Co}_{14} \mathrm{Cu}_{27} / \mathrm{C}$ catalyst achieves 10 times (4 times) higher in mass activity and area activity $\left(15.04 \mathrm{~A} \mathrm{mg}^{-1} \mathrm{pt}_{1}, 114.93 \mathrm{~mA} \mathrm{~cm}^{-2}\right)$ than that of $\mathrm{Pt} / \mathrm{C}$ catalyst $\left(1.45 \mathrm{~A} \mathrm{mg}^{-1} \mathrm{pt}, 27.48 \mathrm{~mA} \mathrm{~cm}^{-2}\right)$ at peak potential for MOR (Fig. 3b). In addition, the MOR performance of PtNiFe$\mathrm{CoCu}_{26} / \mathrm{C}$ catalyst is similar to that of the $\mathrm{Pt}_{18} \mathrm{Ni}_{26} \mathrm{Fe}_{15} \mathrm{Co}_{14} \mathrm{Cu}_{27} /$ $\mathrm{C}$ catalyst, the MOR performance of $\mathrm{Pt}_{21} \mathrm{Ni}_{27} \mathrm{Fe}_{19} \mathrm{Co}_{17} \mathrm{Cu}_{16} / \mathrm{C}$ and $\mathrm{Pt}_{15} \mathrm{Ni}_{24} \mathrm{Fe}_{13} \mathrm{Co}_{13} \mathrm{Cu}_{35} / \mathrm{C}$ catalysts is slightly lower than the $\mathrm{Pt}_{18} \mathrm{Ni}_{26} \mathrm{Fe}_{15} \mathrm{Co}_{14} \mathrm{Cu}_{27} / \mathrm{C}$ catalyst. (Supplementary Fig. 26 and Supplementary Table 6). Moreover, among recently reported the Pt-based materials for MOR in alkaline medium, the $\mathrm{Pt}_{18} \mathrm{Ni}_{26}$ $\mathrm{Fe}_{15} \mathrm{Co}_{14} \mathrm{Cu}_{27} / \mathrm{C}$ catalyst exhibits higher mass activity (Supplementary Table 8).

To study the stability of the $\mathrm{Pt}_{18} \mathrm{Ni}_{26} \mathrm{Fe}_{15} \mathrm{Co}_{14} \mathrm{Cu}_{27} / \mathrm{C}$ and $\mathrm{Pt} / \mathrm{C}$ catalysts in MOR, the chronoamperometry test at $0.65 \mathrm{~V}$ vs. RHE and $1000 \mathrm{CV}$ cycles were executed. After $5000 \mathrm{~s}$ chronoamperometry test (Fig. 3c), the $\mathrm{Pt}_{18} \mathrm{Ni}_{26} \mathrm{Fe}_{15} \mathrm{Co}_{14} \mathrm{Cu}_{27} / \mathrm{C}\left(3.79 \mathrm{~A} \mathrm{mg}^{-1}\right.$ pt) catalyst shows higher stability than that of commercial $\mathrm{Pt} / \mathrm{C}(0.20$ A mg ${ }^{-1}$ t). After $1000 \mathrm{CV}$ cycles, the mass activity of the $\mathrm{Pt}_{18} \mathrm{Ni}_{26} \mathrm{Fe}_{15} \mathrm{Co}_{14} \mathrm{Cu}_{27} / \mathrm{C}$ and $\mathrm{Pt} / \mathrm{C}$ catalysts decay by about $6.4 \%$ and $26.9 \%$ (Fig. 3d and Supplementary Fig. 28a), further confirmed the excellent stability of $\mathrm{Pt}_{18} \mathrm{Ni}_{26} \mathrm{Fe}_{15} \mathrm{Co}_{14} \mathrm{Cu}_{27} / \mathrm{C}$ catalyst. From Supplementary Figs. 27, 28, the order of catalysts stability is as follows: $\mathrm{Pt}_{18} \mathrm{Ni}_{26} \mathrm{Fe}_{15} \mathrm{Co}_{14} \mathrm{Cu}_{27} / \mathrm{C} \approx \mathrm{PtNiFeCoCu} \mathrm{Pu}_{26} /$ $\mathrm{C}>\mathrm{Pt}_{21} \mathrm{Ni}_{27} \mathrm{Fe}_{19} \mathrm{Co}_{17} \mathrm{Cu}_{16} / \mathrm{C}>\mathrm{Pt}_{15} \mathrm{Ni}_{24} \mathrm{Fe}_{13} \mathrm{Co}_{13} \mathrm{Cu}_{35} / \mathrm{C}$. And the morphology and element ratio of $\mathrm{PtNiFeCoCu} / \mathrm{C}$ catalyst with different rations did not obvious change after stability test (Supplementary Figs. 29, 30, Supplementary Table 1). However, the $\mathrm{Pt} / \mathrm{C}$ catalyst shows obvious aggregation after the stability test (Supplementary Fig. 30d). XPS spectrum (Supplementary Fig. 31) shows that the Pt $4 \mathrm{f}, \mathrm{Ni} 2 \mathrm{p}, \mathrm{Fe} 2 \mathrm{p}$, Co $2 \mathrm{p}$, and $\mathrm{Cu} 2 \mathrm{p}$ spectra of $\mathrm{Pt}_{18} \mathrm{Ni}_{26} \mathrm{Fe}_{15} \mathrm{Co}_{14} \mathrm{Cu}_{27} / \mathrm{C}$ were very similar before and after MOR electrocatalysis. These test results indicate that the NPs-HEAs catalyst achieves double enhancement of catalytic activity and stability.

In MOR, the main route for catalyst deactivation is the poisoning effect of CO intermediates ${ }^{40-42}$. The $I_{\mathrm{f}} / I_{\mathrm{b}}$ ( $I_{\mathrm{f}}$ : forward current density, $I_{\mathrm{b}}$ : backward current density) ratio of $\mathrm{Pt}_{18} \mathrm{Ni}_{26}$ $\mathrm{Fe}_{15} \mathrm{Co}_{14} \mathrm{Cu}_{27} / \mathrm{C}$ catalyst (3.26) is larger than that of $\mathrm{Pt} / \mathrm{C}$ (2.31), which shows the strong $\mathrm{CO}$ anti-poisoning performance of $\mathrm{Pt}_{18} \mathrm{Ni}_{26} \mathrm{Fe}_{15} \mathrm{Co}_{14} \mathrm{Cu}_{27} / \mathrm{C}$ catalyst. And from CO stripping curves (Supplementary Fig. 32), the onset potentials of the $\mathrm{Pt}_{18} \mathrm{Ni}_{26}$ $\mathrm{Fe}_{15} \mathrm{Co}_{14} \mathrm{Cu}_{27} / \mathrm{C}(0.391 \mathrm{~V}$ vs. RHE) display a $181 \mathrm{mV}$ decrease compared with $\mathrm{Pt} / \mathrm{C}(0.572 \mathrm{~V}$ vs. $\mathrm{RHE})$ catalyst. $\mathrm{PtNiFeCoCu} 26 / \mathrm{C}$ (0.398 V vs. RHE), $\mathrm{Pt}_{21} \mathrm{Ni}_{27} \mathrm{Fe}_{19} \mathrm{Co}_{17} \mathrm{Cu}_{16} / \mathrm{C}$ (0.395 V vs. RHE), and $\mathrm{Pt}_{15} \mathrm{Ni}_{24} \mathrm{Fe}_{13} \mathrm{Co}_{13} \mathrm{Cu}_{35} / \mathrm{C}(0.413 \mathrm{~V}$ vs. RHE) catalysts have analogous onset potentials to $\mathrm{Pt}_{18} \mathrm{Ni}_{26} \mathrm{Fe}_{15} \mathrm{Co}_{14} \mathrm{Cu}_{27} / \mathrm{C}$. It further shows that the $\mathrm{PtNiFeCoCu} / \mathrm{C}$ catalyst has better $\mathrm{CO}$ antipoisoning performance. 
a

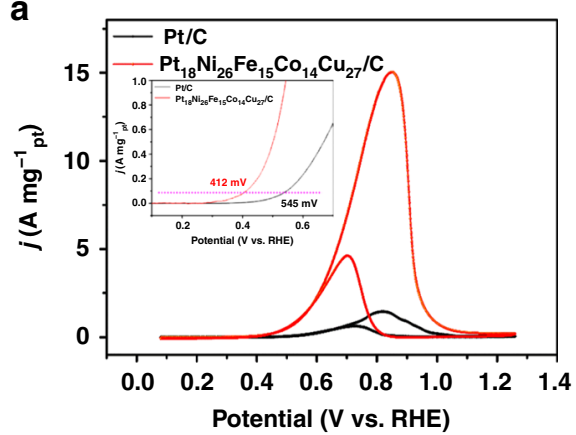

C

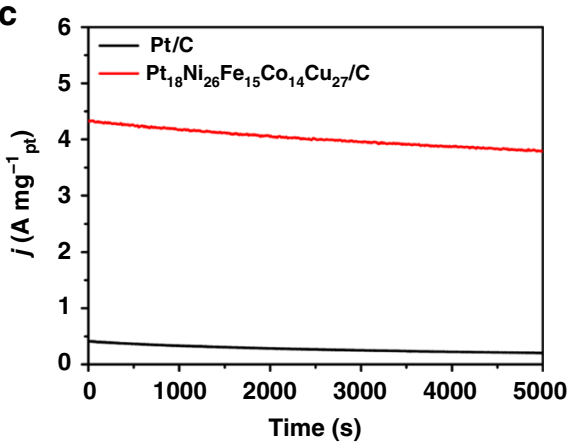

b

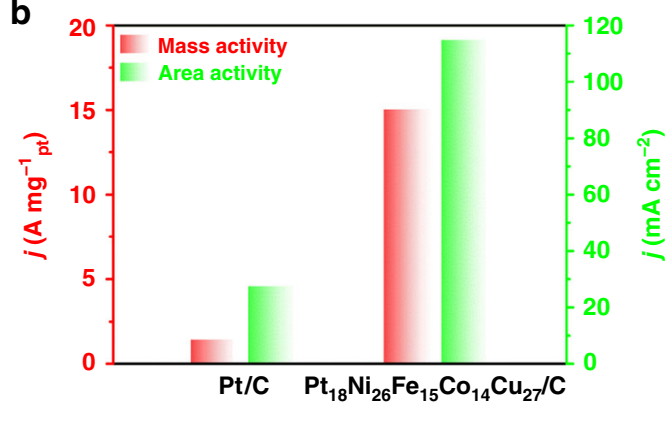

d

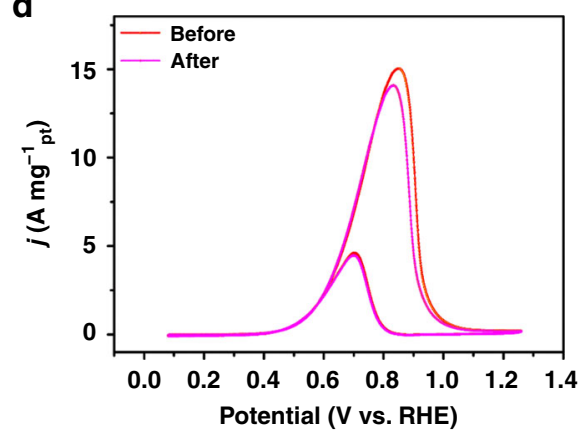

Fig. 3 Methanol electro-oxidation performance of the $\mathrm{Pt}_{18} \mathbf{N i}_{26} \mathrm{Fe}_{15} \mathrm{CO}_{14} \mathrm{Cu}_{27} / \mathrm{C}$ and $\mathrm{Pt} / \mathrm{C}$ in $\mathbf{1} \mathbf{M ~ K O H}+1 \mathbf{M ~ C H} \mathbf{C H}_{3}$ electrolyte. a CV curves (the inset is the onset potential, the mass activity of $0.1 \mathrm{~A} \mathrm{mg}^{-1}{ }_{\mathrm{pt}}$ ) of $\mathrm{Pt} / \mathrm{C}$ and $\mathrm{Pt}_{18} \mathrm{Ni}_{26} \mathrm{Fe}_{15} \mathrm{Co}_{14} \mathrm{Cu}_{27} / \mathrm{C}$. $\mathbf{b}$ Peak values of mass activity and area activity. c Chronoamperometric tests for MOR at $0.65 \mathrm{~V}$ vs. RHE. d CV curves of the $\mathrm{Pt}_{18} \mathrm{Ni}_{26} \mathrm{Fe}_{15} \mathrm{Co}_{14} \mathrm{Cu}_{27} / \mathrm{C}$ before and after 1000 cycles.

DFT studies. We applied periodic DFT calculations to explore the HER and MOR performances in HEA. It is well known that the surface composition of the catalyst affects the catalytic performance. We use $\mathrm{Ar}^{+}$sputtering to study the change in surface element content of the $\mathrm{PtNiFeCoCu} \mathrm{NPs}{ }^{43}$. After $\mathrm{Ar}^{+}$sputtering for $10 \mathrm{~s}$, the relative content of the elements has been reduced, but the reduced contents of $\mathrm{Ni}, \mathrm{Cu}$, and $\mathrm{Fe}$ were slightly higher than that of Pt and Co (Supplementary Table 4). We have also compared the PDOS of the HEA with slightly different stoichiometry. As shown in Supplementary Fig. 33, the comparison models show the highly similar electronic structure with the models applied in the work, in which the peak positions and patterns of $\mathrm{d}$ orbitals in each element display very limited change. Therefore, the slight stoichiometry variations of the HEA will not significantly affect the electronic structure of the PDOS results. Based on this, after a detailed comparison of different random atomic arrangements, the HEA structure with slightly $\mathrm{Ni}$ and $\mathrm{Cu}$ enriched surface has been applied as the lattice model due to the highest stability (Fig. 4a). From the side view, the lattice has shown a highly stable structure, in which the lattice shows subtle distortion after relaxation, which indicates good durability for electrocatalysis. Meanwhile, the surface $\mathrm{Ni}$ and Co dominate the electroactive region near the Fermi level $\left(E_{\mathrm{F}}\right)$ (Fig. $4 \mathrm{~b}$ ). To further understand the electronic structures, the partial projected density of states (PDOSs) of each element in HEA has been illustrated. Notably, Pt-5d occupies the deepest position near $E_{\mathrm{V}}-4.5 \mathrm{eV}(\mathrm{EV}=0 \mathrm{eV})$, playing as the electron reservoir for the reduction process such as HER. Both Co-3d and Ni-3d orbitals dominate the bands near $E_{\mathrm{F}}$, which locate at $E_{\mathrm{V}}-1.0 \mathrm{eV}$, contributing to the electron depletion center for HER and MOR. Moreover, the 3d orbitals of $\mathrm{Cu}, \mathrm{Co}$, and Fe not only alleviate the energy barrier of dual-way electron transfer for the oxidation and reduction process but also facilitate the stabilization of intermediates for MOR (Fig. 4c). A detailed study of the site-dependent PDOSs of each element was illustrated (Fig. 4d). Notably, only the surface Pt demonstrates an evident upshift towards the $E_{\mathrm{F}}$, which promotes the electron transfer for the HEA surfaces. Fe shows a site-independent electronic structure within HEA, which preserves the stable adsorption of intermediates with stronger anti-poisoning capability for the MOR process. From the bulk structure to the surface site, Co sites display an alleviation of the $e_{g}-t_{2 g}$ splitting effect, supporting an enhanced electron transfer efficiency for electrocatalysis. Both $\mathrm{Ni}$ exhibits the relatively stable d-bandcenter to maintain the electroactive electron boosting center. For $\mathrm{Cu}$ sites closer to the surface, the $3 \mathrm{~d}$ orbitals show a slight upshift trend to support the electroactivity of the HEA. Thus, the synergistic effect of multi-active sites on the HEA surface determines the remarkable performance of HER and MOR (Fig. 4d). For the HER process, the initial adsorption of water determines the efficiency of water-splitting and the following proton transfer. For the water adsorption process, the evident downshift of $s, p$ orbitals in $\mathrm{H}_{2} \mathrm{O}$ has been noticed, which confirms the active electron transfer from the HEA to the water to achieve the stable adsorption and lays a good foundation for the following water dissociation (Fig. 4e). Similarly, we notice the adsorption of $\mathrm{CH}_{3} \mathrm{OH}$ on HEA indicates the evident downshifting of $s, p$ bands, and overlapping with electroactive $\mathrm{d}$ orbitals of the surface (Fig. 4f). For the multi-electron involved MOR process, the linear correlation of intermediates transformation is the key to guarantee the proton and electron transfer. Such a linear correlation is noticed for the $s, p$ orbitals of key intermediates along the MOR process, which not only supports the efficient oxidation of the intermediates but also leads to the optimal binding strength during the intermediate transformation. Thus, superior MOR performance is guaranteed in the HEA (Fig. 4g).

Then, we further interpret the reaction trend for both HER and MOR from both the structural configuration and energetic reaction pathways. The most stable structural configurations of four key initial reactants and intermediates have been displayed. 

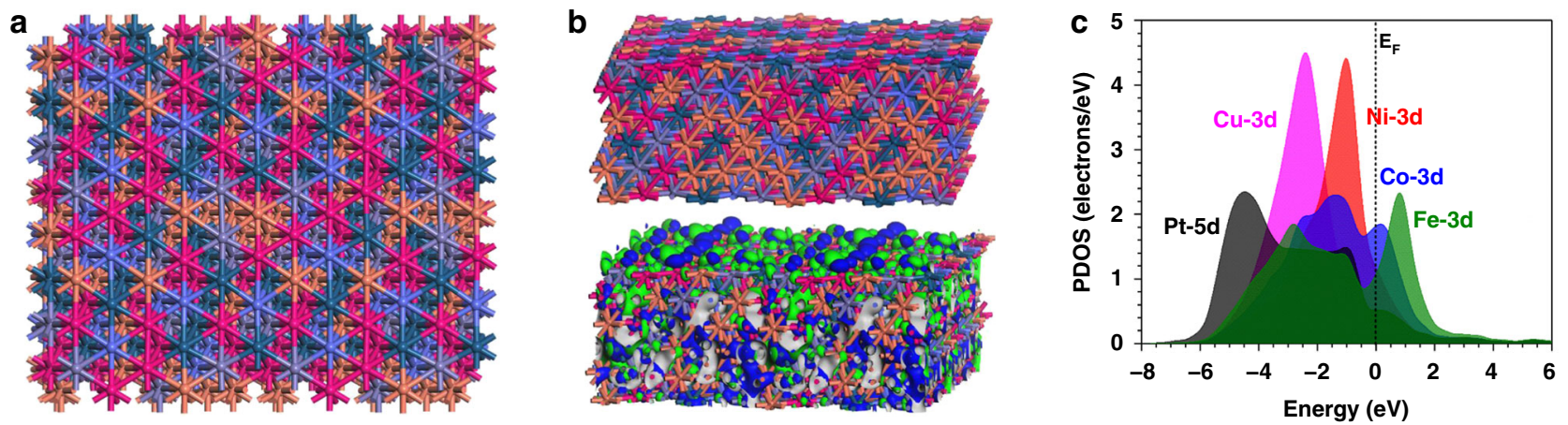

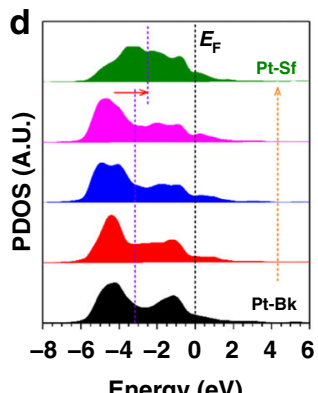

Energy (eV)

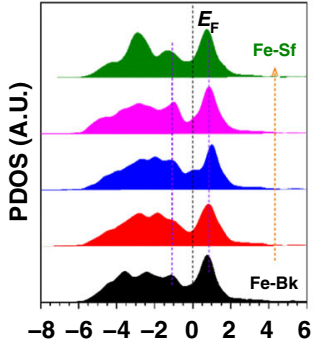

Energy (eV)

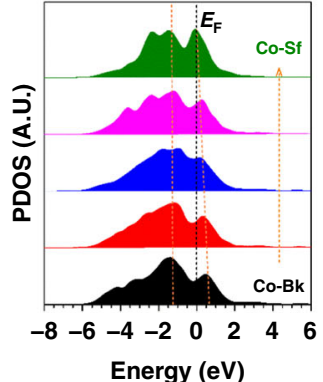

Energy (eV)

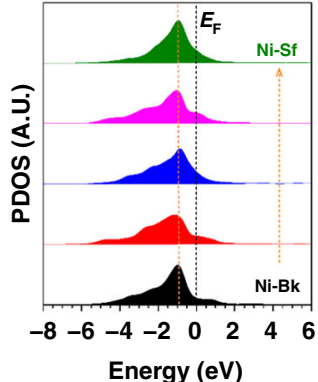

Energy (eV)
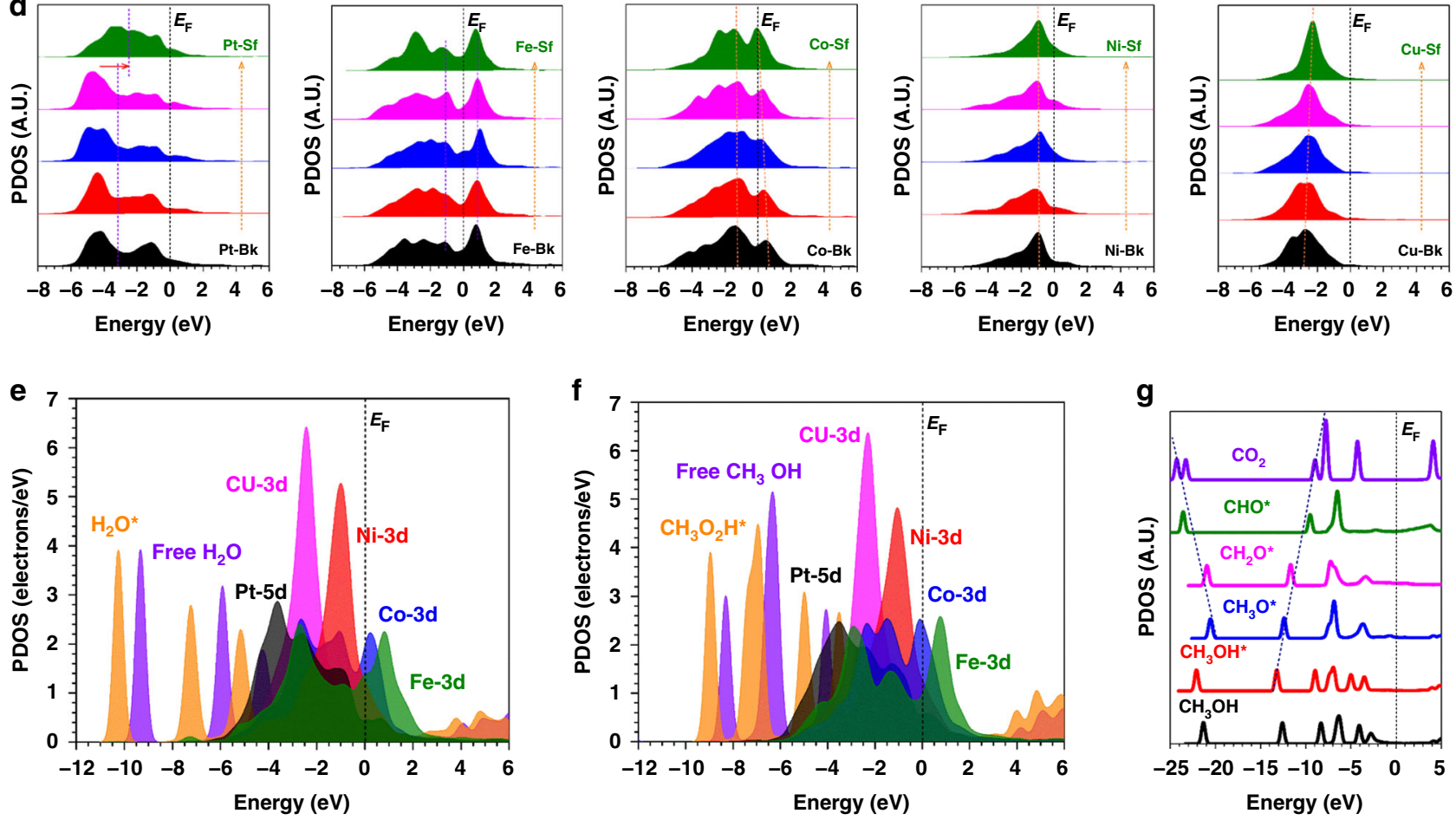

Fig. 4 Density functional theory calculations for the structural configuration and PDOSs. a The side view of the structural configuration of HEA. $\mathbf{b}$ The side view of HEA structural configuration and the real spatial contour plots for bonding and anti-bonding orbitals near $E_{F}$. And the top view of the real spatial contour plots for bonding and anti-bonding orbitals near $E_{\mathrm{F}}$ for the HEA. Dark green balls $=\mathrm{Pt}$; Gray balls $=\mathrm{Fe} ; \mathrm{Blue}$ balls $=\mathrm{Co}$; Pink balls $=\mathrm{Ni}$ and Orange balls $=\mathrm{Cu}$. $\mathbf{c}$ The PDOSs of the HEA. d The site-dependent PDOSs of Pt, Fe, Co, Ni, and Cu in HEA. e The PDOSs for the water adsorption. $\mathbf{f}$ The PDOSs for the $\mathrm{CH}_{3} \mathrm{OH}$ adsorption. $\mathbf{g}$ The PDOSs for the key intermediates of MOR.

The most stable adsorption of $\mathrm{CH}_{3} \mathrm{OH}$ and $\mathrm{H}_{2} \mathrm{O}$ locates near $\mathrm{Ni}$ and $\mathrm{Fe}$ sites, respectively. The $\mathrm{OH}$ is stabilized in the neighboring hollow sites, which avoids the active site blocking during both HER and MOR. Meanwhile, the $\mathrm{H}$ adsorption prefers the hollow site near $\mathrm{Ni}$ and $\mathrm{Co}$, which is distinct from the $\mathrm{OH}$. Thus, the multi-site adsorption for HER and MOR process on HEA guarantees superior performances (Fig. 5a). Moreover, we have supplied the adsorption sites mapping of the surface to support the HER mechanism (Fig. 5b). Notably, the different sites in HEA surfaces demonstrated very varied adsorption preference for the intermediates. For HER, the initial adsorption of $\mathrm{H}_{2} \mathrm{O}$ locates on the $\mathrm{Fe}$ sites, which activates the dissociation of water molecules and facilitates the stabilization of ${ }^{*} \mathrm{OH}$ in the neighboring hollow sites. Meanwhile, the nearby $\mathrm{Ni}$, Co show the relatively preferred $\mathrm{H}^{*}$ adsorption after the water dissociation, leading to the stabilization of $\mathrm{H}$ in the hollow sites surrounded by $\mathrm{Co}$ and $\mathrm{Ni}$. The generated $\mathrm{H}_{2}$ shows overall weak binding to the surface, indicating the quick desorption process to guarantee the efficient HER process. Therefore, our additional information has supplied the binding stability of the intermediates for the HER process, which supports the Volmer-Heyrovsky mechanism. The HER process supports a continuous downhill trend, confirming the efficient proton and electron transfer (Fig. 5c). Owing to the multi-active sites for $\mathrm{OH}$ and $\mathrm{H}$, the water dissociation demonstrates a low activation barrier of $0.11 \mathrm{eV}$ for the transition state (Fig. $5 \mathrm{~d}$ ). For the MOR process, the rate-determining step occurs at $\left[\mathrm{CHO}^{*}+3^{*} \mathrm{OH}+3 \mathrm{H}_{2} \mathrm{O}\right]$ to $[\mathrm{HCOOH}+2 * \mathrm{OH}+$ $4 \mathrm{H}_{2} \mathrm{O}$ ] with the largest energy barrier of $0.45 \mathrm{eV}$. The transition state displays the activation energy of $0.64 \mathrm{eV}$. The overall MOR process is exothermic, which releases $2.34 \mathrm{eV}$ energy (Fig. 5e). The anti-poisoning capability is another essential requirement for the long-term application of MOR electrocatalysts. Compared to $\mathrm{MOR}$, the formation of $\mathrm{CO}$ shows a much larger energy barrier of $0.81 \mathrm{eV}$ and activation energy $(0.94 \mathrm{eV})$, resulting in the suppression of the $\mathrm{CO}$ poisoning. The holistic reaction trend of the $\mathrm{CO}$ poisoning mechanism is also much weaker than the MOR process, which explains both the superior electroactivity and durability of the HEA (Fig. 5f). 
a
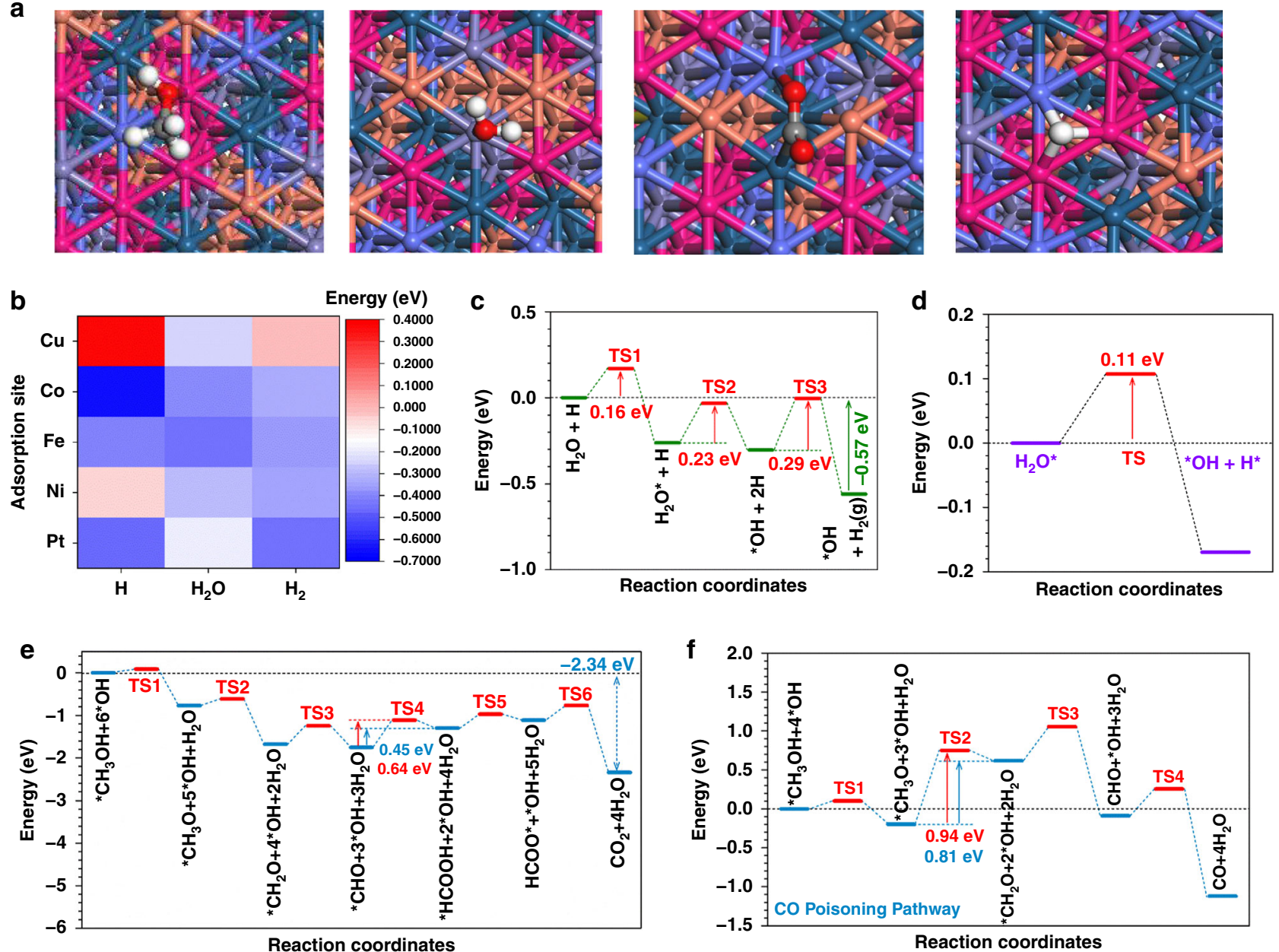

Fig. 5 Density functional theory calculations for the structural configuration and energetic reaction pathways. a The structural configuration of stable adsorption of key intermediates in HER and MOR. From left to right: $\mathrm{CH}_{3} \mathrm{OH}, \mathrm{H}_{2} \mathrm{O}, \mathrm{CO}_{2}, \mathrm{H}$. Dark green balls $=$ Pt; Gray balls $=$ Fe; Blue balls $=\mathrm{Co}$; Pink balls $=\mathrm{Ni}$; Orange balls $=\mathrm{Cu}$; Red balls $=\mathrm{O}$ and White balls $=\mathrm{H}$. $\mathbf{b}$ The binding energy mapping of HER. $\mathbf{c}$ The energetic pathway of the alkaline HER. d The activation energies of water dissociation. e The energetic pathway of the alkaline MOR. $\mathbf{f}$ The energetic pathway of CO poisoning.

\section{Discussion}

In summary, we have synthesized the uniform and small size $\mathrm{Pt}_{18} \mathrm{Ni}_{26} \mathrm{Fe}_{15} \mathrm{Co}_{14} \mathrm{Cu}_{27}$ NPs HEA nanoparticles by a simple lowtemperature synthesis method at atmospheric pressure. Electrocatalytic test results showed that the obtained $\mathrm{Pt}_{18} \mathrm{Ni}_{26} \mathrm{Fe}_{15}$ $\mathrm{Co}_{14} \mathrm{Cu}_{27} / \mathrm{C}$ catalyst has excellent bi-functional electrocatalytic properties for reduction reaction (HER) and oxidation reaction (MOR). $\mathrm{Pt}_{18} \mathrm{Ni}_{26} \mathrm{Fe}_{15} \mathrm{Co}_{14} \mathrm{Cu}_{27} / \mathrm{C}$ catalyst showed an ultrasmall overpotential $\left(11 \mathrm{mV}\right.$ at $\left.10 \mathrm{~mA} \mathrm{~cm}^{-2}\right)$ and superior activity $\left(10.96 \mathrm{~A} \mathrm{mg}^{-1}{ }_{\mathrm{Pt}}\right.$ at $-0.07 \mathrm{~V}$ vs. RHE) and stability for HER, which is one of the best HER activity in alkaline medium. And it is also the effective catalysts for MOR and displayed the excellent activity (15.04 $\mathrm{A} \mathrm{mg}^{-1} \mathrm{Pt}_{\mathrm{Pt}}$ ) and better $\mathrm{CO}$ anti-poisoning in alkaline solution, which is the best alkaline MOR activity among the ever reported. Through DFT calculations, the origin of remarkable electroactivity and durability of HEA in HER and MOR is attributed to the synergistic effect of each element for efficient electron transfer. The suitable electronic environment of the HEA realizes the multi-active sites for appropriate adsorption of key intermediates and efficient electron transfer during the electrocatalysis, which maximizes the utilization of surface electroactivity. The simple oil phase synthesis strategy proposed in this work, as well as the multi-active sites and fast site-to-site electron transfer mechanism, which is expected to lay the foundation for the preparation of other HEAs and their application in related electrocatalysis.

\section{Methods}

Materials. Platinum (II) acetylacetonate (Pt(acac), $27 \%)$, nickel (II) acetylacetonate $\left(\mathrm{Ni}(\mathrm{acac})_{2}, 95 \%\right)$, Molybdenumhexacarbonyl $\left(\mathrm{Mo}(\mathrm{CO})_{6}, 98 \%\right)$, oleylamine $(\mathrm{OAm},>70 \%)$ and glucose were bought from Sigma-Aldrich. Cupric acetylacetonate $\left(\mathrm{Cu}(\mathrm{acac})_{2}, 98 \%\right)$ was purchased from Energy Chemical. (1-Hexadecyl) trimethylammonium chloride (CTAC, 96\%), Tris(2,4-pentanediaonato) Cobalt (III) $\left(\mathrm{Co}(\mathrm{acac})_{3}, 98 \%\right)$, Iron (III) 2,4-pentanedionate ( $\left.\mathrm{Fe}(\mathrm{acac})_{3}\right)$, Nafion solution ( 5 wt.\%) were supplied by Alfa Aesar. Methanol, cyclohexane, ethanol, and isopropanol were bought from Beijing Tongguang Fine Chemicals Company. Potassium hydroxide $(\mathrm{KOH}, 90 \%)$ was purchased from Aladdin.

Preparation of HEA $\mathbf{P t}_{18} \mathbf{N i}_{26} \mathrm{Fe}_{15} \mathrm{Co}_{14} \mathbf{C u}_{\mathbf{2 7}}$ NPs. CTAC (50 mg) was added into oleylamine $(5 \mathrm{~mL})$ in a $15 \mathrm{~mL}$ vial. After sonication for about $15 \mathrm{~min}, \mathrm{Pt}(\mathrm{acac})_{2}$ (10 mg), Ni(acac) $)_{2}(6.4 \mathrm{mg}), \mathrm{Fe}(\mathrm{acac})_{3}(8.8 \mathrm{mg}), \mathrm{Co}(\mathrm{acac})_{3}(8.9 \mathrm{mg}), \mathrm{Cu}(\mathrm{acac})_{2}$ (6.5 mg), glucose $(60 \mathrm{mg})$, and $\mathrm{Mo}(\mathrm{CO})_{6}(33 \mathrm{mg})$ were added into the vial. In order to obtain a homogeneous solution, the mixture was sonicated for $1 \mathrm{~h}$. The vial was heated to $220^{\circ} \mathrm{C}$ at $5^{\circ} \mathrm{C} \mathrm{min}^{-1}$ and then kept $2 \mathrm{~h}$ under magnetic stirring at $400 \mathrm{rpm}$. The black colloidal products were collected by centrifugation and washed two times with an ethanol/cyclohexane mixture. Finally, the black colloidal products were kept in cyclohexane for further use.

Preparation of alloy PtNiFeCoCu with different element ratios NPs. CTAC $(50 \mathrm{mg})$ was added into oleylamine $(5 \mathrm{~mL})$ in a $15 \mathrm{~mL}$ vial. After sonication for about $15 \mathrm{~min}, \mathrm{Pt}(\mathrm{acac})_{2}(10 \mathrm{mg}), \mathrm{Ni}(\mathrm{acac})_{2}(6.4 \mathrm{mg}), \mathrm{Fe}(\mathrm{acac})_{3}(8.8 \mathrm{mg}), \mathrm{Co}(\mathrm{acac})_{3}$ 
(8.9 mg), $\mathrm{Cu}(\mathrm{acac})_{2}(6.2 \mathrm{mg})$, glucose $(60 \mathrm{mg})$ and $\mathrm{Mo}(\mathrm{CO})_{6}(33 \mathrm{mg})$ were added into the vial. In order to obtain a homogeneous solution, the mixture was sonicated for $1 \mathrm{~h}$. The vial was heated to $220^{\circ} \mathrm{C}$ at $5^{\circ} \mathrm{C} \mathrm{min}-1$ and then kept $2 \mathrm{~h}$ under magnetic stirring at $400 \mathrm{rpm}$. The black colloidal products $\left(\mathrm{PtNiFeCoCu}_{26}\right)$ were collected by centrifugation and washed two times with an ethanol/cyclohexane mixture. Finally, the black colloidal products were kept in cyclohexane for further use. The synthesis of NPs with other element ratios only changes the amount of $\mathrm{Cu}$ $(\mathrm{acac})_{2}$ precursor $(4.0 \mathrm{mg}$ and $8.5 \mathrm{mg})$.

Preparation of PtNiFeCoCu/C. The obtained $1 \mathrm{mg}$ HEA NPs dispersed in $10 \mathrm{~mL}$ cyclohexane was mixed with $4 \mathrm{mg}$ of carbon (Ketjen Black-300) in $10 \mathrm{~mL}$ ethanol under sonication for $1 \mathrm{~h}$, and then the product was collected via centrifugation with ethanol. The $\mathrm{PtNiFeCoCu} / \mathrm{C}$ catalysts were further cleaned (remove organic species) with $0.5 \mathrm{M}$ acetic acid (ethanol solution) under $\mathrm{N}_{2}$ atmosphere. After being sonicating for $2 \mathrm{~h}$, the products were collected by centrifugation and washed with ethanol for three times.

Characterization. The TEM and high-resolution TEM (HRTEM) images of the samples were characterized by an FEI Tecnai-G2 F30 at an accelerating voltage of $300 \mathrm{KV}$. Powder X-ray diffraction (XRD) spectra were recorded on X'Pert-PRO MPD diffractometer operating at $40 \mathrm{kV}$ and $40 \mathrm{~mA}$ with $\mathrm{Cu} \mathrm{Ka}$ radiation. The compositions of the HEA NPs were determined by the inductively coupled plasma atomic emission spectrometer (ICP-AES, Varian 710-ES). The catalysts after the durability tests were scratched off the glassy carbon electrode with the aid of sonication in ethanol and then collected for further TEM, XRD, and ICP characterization. The XPS analyses were carried out with Axis Supra spectrometer using a monochromatic $\mathrm{Al} \mathrm{Ka}$ source $(15 \mathrm{~mA}, 14 \mathrm{kV})$. Survey scan analyses were carried out with an analysis area of $300 \times 700 \mu^{2}$ and a pass energy of $100 \mathrm{eV}$. Highresolution analyses were carried out with an analysis area of $300 \times 700 \mu \mathrm{m}^{2}$ and a pass energy of $30 \mathrm{eV}$. Spectra have been corrected to the main line of the carbon $1 \mathrm{~s}$ spectrum (adventitious carbon) set to $284.8 \mathrm{eV}$. Spectra were analyzed using CasaXPS software (version 2.3.14)

Electrochemical measurements. The $1 \mathrm{mg} \mathrm{PtNiFeCoCu} / \mathrm{C}$ catalysts were dispersed in a mixture of $495 \mu \mathrm{L}$ ultrapure water, $495 \mu \mathrm{L}$ isopropanol, and $10 \mu \mathrm{L}$ Nafion solution, after sonication for $1 \mathrm{~h}, \mathrm{PtNiFeCoCu} / \mathrm{C}$ catalyst with the concentration of $1 \mathrm{mg} \mathrm{mL}^{-1}$ was obtained.

Electrochemical measurements were conducted on a CHI 760E Electrochemical Workstation (Shanghai Chenhua Instrument Corporation, China) in a conventional three-electrode cell. The graphite rod electrode as the counter electrode and a saturated calomel electrode (SCE) as the reference electrode. The working electrode was a glassy carbon electrode (GCE, diameter: $3 \mathrm{~mm}$, area: $0.07065 \mathrm{~cm}^{2}$ ). Ten microliters of the catalyst were dropped onto the GCE surface for further electrochemical tests. All the potentials reported in this work were converted to the reversible hydrogen electrode (RHE). Cyclic voltammograms (CVs) were performed in $\mathrm{N}_{2}$-saturated $1 \mathrm{M} \mathrm{KOH}$ solution from 0 to $1.2 \mathrm{~V}$ vs. RHE at a scan rate of $20 \mathrm{mV} \mathrm{s}^{-1}$. Electrochemical impedance spectroscopy (EIS) measurements were measured at $-50 \mathrm{mV}$ vs. RHE in the frequency range from $10 \mathrm{kHz}$ to $0.01 \mathrm{~Hz}$ in $\mathrm{N}_{2}$-saturated $1 \mathrm{M} \mathrm{KOH}$ solution.

Hydrogen evolution reaction (HER) measurements. The HER performance of the catalysts was evaluated by linear sweep voltammetry (LSV) with a scan rate of $5 \mathrm{mV} \mathrm{s}^{-1}$ in $\mathrm{N}_{2}$-saturated $1 \mathrm{M} \mathrm{KOH}$ solution, and all polarization curves were $95 \%$ iR-corrected. The durability tests were performed in $1.0 \mathrm{M} \mathrm{KOH}$ solution using the chronoamperometric method. And 1000th/10000th CVs were also measured to evaluate the stability of catalysts. $20 \% \mathrm{Pt} / \mathrm{C}$ catalyst was also dropped on the GCE as a reference catalyst for electrochemical tests under the same conditions.

TOF calculation. The CVs curve was collected from 0 to $1.2 \mathrm{~V}$ vs. RHE in $0.5 \mathrm{M}$ $\mathrm{H}_{2} \mathrm{SO}_{4}$ solution with a scan rate of $20 \mathrm{mV} \mathrm{s}^{-1}$ :

$$
\begin{gathered}
n=\frac{Q_{\mathrm{H}}}{2^{*} F}, \\
\operatorname{TOF}\left(\mathrm{S}^{-1}\right)=\frac{\mathrm{I}}{2^{*} F^{*} n},
\end{gathered}
$$

where $n$ is the number of active sites, number 2 represents two electrons (produce one hydrogen molecule), $Q_{\mathrm{H}}$ represents electron transfer quantity (the hydrogen desorption peak), $F$ is Faraday's constant $\left(96485.3 \mathrm{C} \mathrm{mol}^{-1}\right)$, and $I(\mathrm{~A})$ is the current measured at a specific potential during LSV measurement.

Methanol oxidation reaction (MOR) measurements. The CVs for MOR were conducted in $\mathrm{N}_{2}$-saturated $1 \mathrm{M} \mathrm{KOH}+1 \mathrm{M} \mathrm{CH}_{3} \mathrm{OH}$ solution between $0.2-1.2 \mathrm{~V}$ vs. RHE with a scan rate of $20 \mathrm{mV} \mathrm{s}^{-1}$. For the MOR stability tests, chronoamperometric tests were performed at a fixed potential of $0.65 \mathrm{~V}$ vs. RHE, and 1000 th CVs were also performed to evaluate the stability of catalysts.
CO stripping curves were carried out in $\mathbf{1} \mathbf{M} \mathbf{K O H}$ solution. Before the tests, $1 \mathrm{M}$ $\mathrm{KOH}$ solution was first deaerated with high-purity $\mathrm{N}_{2}$. Then, $\mathrm{CO}$ was bubbled into the cell for $15 \mathrm{~min}$ while the potential of the working electrode was held at a constant potential of $0.1 \mathrm{~V}$ vs. RHE. Then $\mathrm{N}_{2}$ was bubbled into the system for 15 min to remove $\mathrm{CO}$ gas. After that, $\mathrm{CO}$ stripping curves were recorded between 0 and $1.2 \mathrm{~V}$ vs. RHE at a scan rate of $20 \mathrm{mV} \mathrm{s}^{-1}$.

Calculation setup. For all the calculations within this work, we have applied the DFT calculations within CASTEP code ${ }^{44}$. The GGA and PBE exchange-correlation functionals are selected for all the calculations ${ }^{45,46}$. The cutoff energy of plane-wave basis sets based on the ultrasoft pseudopotential has been set to $440 \mathrm{eV}$ with the selection of the algorithm Broyden-Fletcher-Goldfarb-Shannon (BFGS) for all the geometry optimizations ${ }^{47}$. To specifically discuss the electrocatalysis on the surface, we have applied the HEA model with similar stoichiometry as experimental characterizations. The HEA model has been built, which consists of 126 atoms in total. The atomic arrangements of different elements are constructed randomly by following the same ratio as the experiments of $\mathrm{Pt}_{18} \mathrm{Ni}_{26} \mathrm{Fe}_{15} \mathrm{Co}_{14} \mathrm{Cu}_{27}$. Based on the components of the HEA by experimental characterizations, $\mathrm{Ni}$ and $\mathrm{Cu}$ have the highest concentration, which is $26 \%$ and $27 \%$, respectively. To determine the most possible preferred model, we have compared the total energy of the HEA model with different surface arrangements, in which the present applied model with $\mathrm{Cu}$ and Ni slight rich feature has been the most stable one. Therefore, we have applied the HEA surface model with $\mathrm{Cu}$ and $\mathrm{Ni}$ rich feature. The reaction energy has been considered based on the intermediate adsorptions on the surface ${ }^{34}$. The

Monkhost-Pack reciprocal space integration was performed using coarse k-points with a mesh of $2 \times 2 \times 1^{48}$, which was guided by the initial convergence test. With these settings, the overall total energy for each step is converged to less than $5.0 \times 10^{-5} \mathrm{eV}$ per atom. The Hellmann-Feynman forces on the atom were converged to less than $0.001 \mathrm{eV} / \AA$.

\section{Data availability}

The data that support the findings of this study are available from the corresponding author upon reasonable request.

\section{Code availability}

All code supporting the findings of this study are available from the corresponding author on request.

Received: 23 July 2020; Accepted: 6 October 2020; Published online: 28 October 2020

\section{References}

1. Glenk, G. \& Reichelstein, S. Economics of converting renewable power to hydrogen. Nat. Energy 4, 216-222 (2019).

2. Seh, Z. W. et al. Combining theory and experiment in electrocatalysis: Insights into materials design. Science 355, 146-157 (2017).

3. Lai, J. \& Guo, S. Design of ultrathin Pt-based multimetallic nanostructures for efficient oxygen reduction electrocatalysis. Small 13, 1702156 (2017).

4. Yin, H. et al. 2D Electrocatalysts for converting earth-abundant simple molecules into value-added commodity chemicals: recent progress and perspectives. Adv. Mater. 32, 1904870 (2019).

5. Leow, W. R. et al. Chloride-mediated selective electrosynthesis of ethylene and propylene oxides at high current density. Science 368, 1228 (2020).

6. Li, L., Wang, P., Shao, Q. \& Huang, X. Metallic nanostructures with low dimensionality for electrochemical water splitting. Chem. Soc. Rev. 49, 3072-3106 (2020).

7. Lai, J., Nsabimana, A., Luque, R. \& Xu, G. 3D porous carbonaceous electrodes for electrocatalytic applications. Joule 2, 76-93 (2018).

8. Xie, C. et al. Insight into the design of defect electrocatalysts: from electronic structure to adsorption energy. Mater. Today 31, 47-68 (2019).

9. Jin, H. et al. Emerging two-dimensional nanomaterials for electrocatalysis. Chem. Rev. 118, 6337-6408 (2018).

10. Chen, Y. et al. Phase engineering of nanomaterials. Nat. Rev. Chem. 4, 243-256 (2020).

11. Tian, X., Lu, X. F., Xia, B. Y. \& Lou, X. W. Advanced electrocatalysts for the oxygen reduction reaction in energy conversion technologies. Joule 4, 45-68 (2020).

12. Yuan, Y. et al. Zirconium nitride catalysts surpass platinum for oxygen reduction. Nat. Mater. 19, 282-286 (2020).

13. Batchelor, T. A. A. et al. High-entropy alloys as a discovery platform for electrocatalysis. Joule 3, 834-845 (2019).

14. George, E. P., Raabe, D. \& Ritchie, R. O. High-entropy alloys. Nat. Rev. Mater. 4, 515-534 (2019). 
15. Chen, P. C. et al. Polyelemental nanoparticle libraries. Science 352, 1565-1569 (2016).

16. Koo, W. T., Millstone, J. E., Weiss, P. S. \& Kim, I. D. The design and science of polyelemental nanoparticles. ACS Nano 14, 6407-6413 (2020).

17. Miracle, D. B. \& Senkov, O. N. A critical review of high entropy alloys and related concepts. Acta Mater. 122, 448-511 (2017).

18. Huang, K. et al. Exploring the impact of atomic lattice deformation on oxygen evolution reactions based on a sub- $5 \mathrm{~nm}$ pure face-centred cubic high-entropy alloy electrocatalyst. J. Mater. Chem. A 8, 11938-11947 (2020).

19. Lei, Z. et al. Enhanced strength and ductility in a high-entropy alloy via ordered oxygen complexes. Nature 563, 546-550 (2018).

20. Zhang, W., Liaw, P. K. \& Zhang, Y. Science and technology in high-entropy alloys. Sci. China Mater. 61, 2-22 (2018).

21. Yeh, J. W. et al. Nanostructured high-entropy alloys with multiple principal elements: novel alloy design concepts and outcomes. Adv. Eng. Mater. 6, 299-303 (2004).

22. Guo, C. et al. Intermediate modulation on noble metal hybridized to $2 \mathrm{D}$ metal-organic framework for accelerated water electrocatalysis. Chem $\mathbf{5}$, 2429-2441 (2019).

23. Lv, F. et al. Ir-based alloy nanoflowers with optimized hydrogen binding energy as bifunctional electrocatalysts for overall water splitting. Small Methods 4, 1900129 (2020).

24. Tian, X. et al. Engineering bunched Pt-Ni alloy nanocages for efficient oxygen reduction in practical fuel cells. Science 366, 850-856 (2019).

25. Xiong, L. et al. Octahedral gold-silver nanoframes with rich crystalline defects for efficient methanol oxidation manifesting a CO-promoting effect. Nat. Commun. 10, 3782 (2019).

26. Zhang, G. et al. High entropy alloy as a highly active and stable electrocatalyst for hydrogen evolution reaction. Electrochim. Acta 279, 19-23 (2018).

27. Glasscott, M. W. et al. Electrosynthesis of high-entropy metallic glass nanoparticles for designer, multi-functional electrocatalysis. Nat. Commun. 10, 2650 (2019).

28. Jin, Z. et al. Nanoporous Al-Ni-Co-Ir-Mo high-entropy alloy for record-high water splitting activity in acidic environments. Small 15, 1904180 (2019).

29. Qiu, H. J. et al. Nanoporous high-entropy alloys for highly stable and efficient catalysts. J. Mater. Chem. A 7, 6499-6506 (2019).

30. Xie, P. et al. Highly efficient decomposition of ammonia using high-entropy alloy catalysts. Nat. Commun. 10, 4011 (2019).

31. Yao, C. Z. et al. Electrochemical preparation and magnetic study of Bi-Fe-Co-Ni-Mn high entropy alloy. Electrochim. Acta 53, 8359-8365 (2008).

32. Soare, V. et al. Electrochemical deposition and microstructural characterization of AlCrFeMnNi and AlCrCuFeMnNi high entropy alloy thin films. Appl. Surf. Sci. 358, 533-539 (2015).

33. Nellaiappan, S. et al. High-entropy alloys as catalysts for the $\mathrm{CO}_{2}$ and $\mathrm{CO}$ reduction reactions: Experimental realization. ACS Catal. 10, 3658-3663 (2020).

34. Pedersen, J. K., Batchelor, T. A. A., Bagger, A. \& Rossmeisl, J. High-entropy alloys as catalysts for the $\mathrm{CO}_{2}$ and $\mathrm{CO}$ reduction reactions. ACS Catal. 10, 2169-2176 (2020).

35. Yao, Y. et al. Carbothermal shock synthesis of high-entropy-alloy nanoparticles. Science 359, 1489-1494 (2018).

36. Luo, X. et al. Spin regulation on $2 \mathrm{D}$ Pd-Fe-Pt nanomeshes promotes fuel electrooxidations. Nano Lett. 20, 1967-1973 (2020).

37. Xie, Y. et al. Boosting water dissociation kinetics on Pt-Ni nanowires by Ninduced orbital tuning. Adv. Mater. 31, 1807780 (2019).

38. $\mathrm{Li}, \mathrm{T}$. et al. Galvanic replacement mediated $3 \mathrm{D}$ porous $\mathrm{PtCu}$ nano-frames for enhanced ethylene glycol oxidation. Chem. Commun. 55, 14526-14529 (2019).

39. Ding, J., Shao, Q., Feng, Y. \& Huang, X. Ruthenium-nickel sandwiched nanoplates for efficient water splitting electrocatalysis. Nano Energy 47, 1-7 (2018).

40. Li, H. et al. Surface oxygen-mediated ultrathin PtRuM (Ni, Fe, and Co) nanowires boosting methanol oxidation reaction. J. Mater. Chem. A 8, 2323-2330 (2020).

41. Chen, L. et al. Improved ethanol electrooxidation performance by shortening $\mathrm{Pd}-\mathrm{Ni}$ active site distance in Pd-Ni-P nanocatalysts. Nat. Commun. 8, 14136 (2017).

42. Huang, W. et al. Highly active and durable methanol oxidation electrocatalyst based on the synergy of platinum-nickel hydroxide-graphene. Nat. Commun. 6, 10035 (2015).
43. You, B. et al. Universal surface engineering of transition metals for superior electrocatalytic hydrogen evolution in neutral water. J. Am. Chem. Soc. 139 , 12283-12290 (2017).

44. Stewart, J. C. et al. First principles methods using CASTEP. Z. Krist.-Cryst. Mater. 220, 567-570 (2005)

45. Perdew, J. P., Burke, K. \& Ernzerhof, M. Generalized gradient approximation made simple. Phys. Rev. Lett. 77, 3865-3868 (1996).

46. Perdew, J. P. et al. Atoms, molecules, solids, and surfaces: applications of the generalized gradient approximation for exchange and correlation. Phys. Rev. B 46, 6671-6687 (1992)

47. Head, J. D. \& Zerner, M. C. A Broyden-Fletcher-Goldfarb-Shanno optimization procedure for molecular geometries. Chem. Phys. Lett. 122 264-270 (1985).

48. Probert, M. I. J. \& Payne, M. C. Improving the convergence of defect calculations in supercells: An ab initio study of the neutral silicon vacancy. Phys. Rev. B 67, 075204 (2003).

\section{Acknowledgements}

This work was supported by the National Natural Science Foundation of China (21571112, 51572136, 51772162, 51802171), the Taishan Scholars Program, Natural Science Foundation of Shandong Province, China (ZR2018BB031), Open Fund of the Key Laboratory of Eco-chemical Engineering (Qingdao University of Science and Technology, No. KF1702), the Taishan Scholar Project of Shandong Province (tsqn201909123)

\section{Author contributions}

L.W. and J.L. conceived and supervised the research. J.L. and H.L. designed the experiments. H.L. performed most of the experiments and data analysis. B.H. performed the DFT calculations and mechanistic analysis. Y.H. and H.Z. prepared the electrodes and helped with electrochemical measurements. W.Q. and D.Z. conducted and analyzed HRTEM micrographs and mapping images. Y.Y. performed and analyzed XRD and ICP measurements. S.L. and W.C. analyzed XPS measurements. All authors discussed the results and commented on the manuscript.

\section{Competing interests}

The authors declare no competing interests.

\section{Additional information}

Supplementary information is available for this paper at https://doi.org/10.1038/s41467020-19277-9.

Correspondence and requests for materials should be addressed to J.L., B.H. or L.W.

Peer review information Nature Communications thanks Jan Philipp Hofmann, Frederik Tielens and other, anonymous, reviewers for their contributions to the peer review of this work. Peer review reports are available.

Reprints and permission information is available at http://www.nature.com/reprints

Publisher's note Springer Nature remains neutral with regard to jurisdictional claims in published maps and institutional affiliations.

Open Access This article is licensed under a Creative Commons Attribution 4.0 International License, which permits use, sharing, adaptation, distribution and reproduction in any medium or format, as long as you give appropriate credit to the original author(s) and the source, provide a link to the Creative Commons license, and indicate if changes were made. The images or other third party material in this article are included in the article's Creative Commons license, unless indicated otherwise in a credit line to the material. If material is not included in the article's Creative Commons license and your intended use is not permitted by statutory regulation or exceeds the permitted use, you will need to obtain permission directly from the copyright holder. To view a copy of this license, visit http://creativecommons.org/ licenses/by/4.0/.

(c) The Author(s) 2020 